\title{
HYPOTHYROIDISM CAUSED BY THALIDOMIDE
}

Sir,

Thalidomide, a glutamic acid derivative, was withdrawn from clinical use in 1962 due to its severe teratogenic effects. Its recent reinstitution in clinical practice was related to its benefits in leprosy and multiple myeloma. ${ }^{[1]}$ However, thalidomide use is 
associated with several side effects. ${ }^{[2]}$ We observed a patient presenting with symptomatic hypothyroidism with elevated TSH level after treatment with thalidomide for multiple myeloma.

A 30-year-old female initially presented with backache and passing of whitish urine, associated with facial puffiness. She was diagnosed as having multiple myeloma. Patient had neck swelling, but her thyroid functions were normal at that time except for a small decrease in TSH level. Her thyroid profile was as follows (normal ranges are shown in brackets): $\mathrm{T}_{3}-1.61 \mathrm{ng} / \mathrm{ml}$ (0.6-1.81 $\mathrm{ng} / \mathrm{ml}) ; \mathrm{T} 4$ - $10.1 \mu \mathrm{g} / \mathrm{dl}(3.2-12.6 \mu \mathrm{g} / \mathrm{dl}) ; \mathrm{TSH}$ - $0.1 \mu \mathrm{lU} / \mathrm{ml}(0.35-5.5 \mu \mathrm{lU} / \mathrm{ml})$; and Free $\mathrm{T}_{4}$ $1.9 \mathrm{ng} / \mathrm{dl}(0.8-2.4 \mathrm{ng} / \mathrm{dl})$. Her weight was 49 $\mathrm{kg}$. She was started on Vincristine, Adriamycin, Dexamethasone (VAD) chemotherapy. Thalidomide $100 \mathrm{mg}$ twice daily was also started. Six months later, the patient presented with obesity (weight $70 \mathrm{~kg}$ ), hoarseness of voice, amenorrhea and nonpitting bilateral edema. Her thyroid profile showed features of hypothyroidism $\left(\mathrm{T}_{3}-0.2\right.$ $\mathrm{ng} / \mathrm{ml} ; \mathrm{T}_{4}-0.44 \mu \mathrm{g} / \mathrm{dl}$; TSH - $100 \mu \mathrm{lU} / \mathrm{ml}$; Free $\left.\mathrm{T}_{4}-0.1 \mathrm{ng} / \mathrm{dl}\right)$. She was started on thyroxine $\left(T_{4}\right) 150 \mu g$ daily.

After 3 months of follow-up, patient was symptomatically better. There was significant loss of weight $(65 \mathrm{~kg})$ and also improvement in the voice. There was no pedal edema. Thyroid profile was as follows: $\mathrm{T}_{3}-2.26 \mathrm{ng} /$ $\mathrm{ml} ; \mathrm{T}_{4}-14.0 \mu \mathrm{g} / \mathrm{dl}$; TSH - $0.14 \mu \mathrm{lU} / \mathrm{ml}$; Free $\mathrm{T}_{4-}-1.6 \mathrm{ng} / \mathrm{dl}$. Thyroxine was stopped as hormone levels were elevated and the patient was advised to have periodic monitoring of thyroid profile. But after 2 months of follow- up, her thyroid profile showed mild hypothyroidism again; hence she was put on thyroxine $50 \mu \mathrm{g}$ daily.

Probability score for this hypothyroidism induced by thalidomide was assessed based on Naranjo's scale ${ }^{[3]}$ and the score was 7 (probable relationship with the suspected drug).

As the number of patients receiving thalidomide increases, adverse effects which were previously unrecognized are now being noticed. Major toxicities of thalidomide are birth defects, peripheral neuropathy, somnolence, rash, fatigue and constipation. Less common side effects include deep venous thrombosis, elevated liver enzymes, malaise, peripheral edema, xerostomia, neutropenia, hypothyroidism, menstrual irregularities, impotence, asthenia, peripheral edema and bradycardia. The incidence and severity of adverse events are related to dose and duration of therapy. Approximately 10\% of patients receiving thalidomide for the treatment of multiple myeloma discontinue therapy secondary to intolerance of drug toxicities. $^{[2]}$

Symptomatic hypothyroidism was seen in our patient of multiple myeloma during treatment with thalidomide. In fact, the several known adverse effects of thalidomide - like constipation, fatigue, lethargy and bradycardia - may be due to the hypothyroidism caused by the drug. Case reports of hypothyroidism due to thalidomide have been reported in the earlier literature also. ${ }^{[4,5]}$ The mechanism involved in induction of hypothyroidism by thalidomide is not clear.
It may be due to the direct toxic effects of the drug on the gland or due to autoimmune damage of the gland due to deregulation of cytokines like interleukin 2, interleukin 6 or interferon gamma. ${ }^{[4]}$

Hypothyroidism is uncommon but rectifiable when it does occur. Early symptoms may well be overlooked because the fatigue may be attributed to thalidomide. Thyroid function should be checked routinely every 3-6 months in patients receiving thalidomide. Thalidomide should be discontinued once a complication that is related to the drug occurs. It can be reinstituted at a $50 \%$ dose reduction, once the symptoms resolve. Physicians need to be aware of the toxicities of thalidomide and the appropriate interventions to be instituted.

\section{REFERENCES}

1. Kyle RA. Current therapy of multiple myeloma. Intern
Med 2002:41:175-80

2. Singhal $S$, Mehta J. Thalidomide in cancer: Potentia uses and limitations. Bio Drugs 2001;15:163-72.

3. Naranjo CA, Busto U, Sellen EM, Sandos P, Ruiz I, Roberts EA, et al. A method for estimating the probability of adverse drug reactiond. Clin Pharmacol Ther 1981;30:239-45.

4. Badros AZ, Siegel E, Bodenner D, Zangari M, Zeldis $\mathrm{J}$, Barlogie B, et al. Hypothyroidism in patients with multiple myeloma following treatment with thalidomide. Am J Med 2002;112:412-3.

5. de Savary N, Lee R, Vaidya B. Severe hypothyroidism after thalidomide treatment. J R Soc Med 2004;97:443.

Mukta N. Chowta, Nithyananda K. Chowta Departments of Pharmacology and *Medicine, Kasturba Medical College, Mangalore, Karnataka, India Kasturba Medical College, Kasturba Medical College,
Mangalore - 575 001, Karnataka, India. E-mail: muktachowta@yahoo.co.in

\section{Author Help: Choosing an appropriate category of article for faster publication}

The manuscript system (www.journalonweb.com) allows the authors to check a likely publication date for a newly submitted article. Based on number of articles in review, number of accepted articles and acceptance rate, the system estimates the likely publication date for an article submitted on a given date.

If there are too many articles in a category e.g., case report, a newly submitted case report if accepted may have to wait for a long period before publication. Hence, the author can check other categories e.g. letter to editor or images, for such paper and submit to another category of articles. 